\title{
Nationhood and Politization of History in School Textbooks: Identity, the Curriculum and Educational Media
}

\author{
Gorana Ognjenović \& Jasna Joselić (red.) \\ Cham: Palgrave Macmillan 2020 \\ 292 sider. ISBN 9783030381219
}
Omtalt av Helge Blakkisrud [seniorforsker, Norsk utenrikspolitisk institutt (NUPI), hb@nupi.no]

I Norden tar vi gjerne historien for gitt. Statens grenser har med få unntak ligget fast gjennom generasjoner, og de færreste stiller spørsmål ved den versjonen av nasjonal historie vi flaskes opp med gjennom skoleverket. Slik er det ikke alle steder. Statene som på 1990-tallet vokste frem fra ruinene av det tidligere Jugoslavia, har erfart at historien kan være både omstridt og uforutsigbar.

Gjennom et halvt århundre hadde jugoslaviske historikere jobbet frem et historisk narrativ som inkluderte alle innbyggere på tvers av etniske og religiøse skillelinjer. Nå gikk de nye nasjonale lederne løs på dette fellesprosjektet og forsøkte å stykke det opp i dets etnonasjonale bestanddeler. Kroatias historie skulle igjen være historien om kroatene, Serbias om serberne, osv. Det som en gang hadde bundet folk sammen, ble definert som kunstig og påtvunget. I prosessen endte ofte gamle medborgere opp som den nye nasjonens erkefiender.

Mens historie som akademisk disiplin ideelt sett er opptatt av å avdekke nye innsikter og sammenhenger, er historie som del av grunnskolepensum et mye mer politisert emne. Det er sistnevnte utgave av historien - den som er skreddersydd for å legitimere stat og regime - som er fokus for Gorana Ognjenović og Jasna Joselićs nye bok Nationhood and Politization of History in School Textbooks. Hvordan reflekteres dagens nye politiske realiteter på Vest-Balkan i omskrivningen av historiepensumet i grunnskolen? Og hvilke følger har denne omskrivningen fătt for forståelsen av hvem som omfattes av det nasjonale fellesskapet?

Boken presenterer er rikt og mangslungent materiale fordelt over femten kapitler. For en som er vant til en relativt «statisk» historie, er Goran Simićs påminnelse betimelig: "In the territory of the former Yugoslavia, in the last 100 years, history started almost from scratch many times, mostly for political reasons» (s. 161). Bare i løpet av det første tiåret før og etter årtusenskiftet gjennomlevde Serbia alene fire 
forskjellige statskonfigurasjoner - alle med behov for sin egen «nasjonale» historie. Dette skaper utfordringer.

Hvordan har forsøkene på å konstruere «ny», post-jugoslavisk historie gått? Redaktørene slår an en pessimistisk grunntone allerede $\mathrm{i}$ bokens dedikasjon: "To the new generation in Southeast Europe who deserves better». Europarådet har helt siden 2. verdenskrig oppfordret europeiske myndigheter til å avpolitisere historiefaget. Men da historisk materialisme og marxisme på begynnelsen av 1990-tallet forsvant som ideologisk rettesnor/tvangstrøye for utformingen av historiepensum på Vest-Balkan, var det ifølge Ognjenović og Joselić det stikk motsatte vi så: Fokus på klassekamp og revolusjon ble erstattet av en søken etter historiske røtter, heltedyrkelse og nasjonal patos - en utvikling som ifølge redaktørene har vært med på å legge grunnlaget for dagens fremvekst av nasjonalisme, fremmedfiendtlighet og populisme.

Antologien inneholder flere gode enkeltbidrag. Mateja Režeks gjennomgang av hvordan etterkrigstidens historiepensum stadig måtte tilpasses skiftende politiske vinder gir en god innføring i hvor krevende det var å skrive sammen de historiske erfaringene som hadde formet de ulike delene av føderasjonen til et felles jugoslavisk historisk og ideologisk prosjekt: Ifølge Režek måtte for eksempel slovenske gymnaselever vente helt til midten av 1960-tallet før de fikk en historiebok som tok for seg den slovenske republikkens rolle i Jugoslavias tilblivelse.

Jeg vil også fremheve Shkëlzen Gashis kapittelbidrag. Gashi går systematisk gjennom hvordan skolebøker i dagens Serbia og Kosovo fremstiller utviklingen i Kosovo fra 2. verdenskrig og frem til Kosovokrigen i 1999. Lærebøkenes narrativer holdes samtidig opp mot en historisk "fasit» av kildebasert, akademisk historie. Selv om analysen til tider kan virke litt skjematisk, viser Gashi med all tydelighet hvordan de to settene med lærebøker selektivt plukker ut og tilpasser historiske hendelser - og til tider også varter opp med ren fiksjon - for at historien skal passe dagens politiske realiteter. Eksempelvis presenterer kosoviske lærebøker de kommunistiske partisanene som kjempet i Kosovo under 2. verdenskrig som en egen «Kosovos nasjonale frigjøringshær» (UNÇK), det vil si som en historisk forløper til Kosovos frigjøringshær (UÇK), organisasjonen som ledet an i selvstendighetskampen på 1990tallet - ifølge forfatteren en ren fiksjon (s. 64).

Når historien skrives med utgangspunkt i dagens politiske realiteter, er det lett å falle for fristelsen til å projisere nasjonale fellesskap bakover i tid: Ulike grupper som har bodd på territoriet gjennom vekslende statsdannelser blir kooptert inn i en velorganisert, lineær historie som peker fremover mot nasjonsbyggernes ideal nasjonalstaten. Som Darko Stojanov og Petar Todorov påpeker i forbindelse med den nykonstruerte enheten Nord-Makedonia: «Textbooks from the fifth elementary grade to the fourth year of high school present Macedonia as an unchangeable category of political geography, a region well defined by its political and economic activities and a specific ethnic group» (s. 229).

Samtidig er historiepensum på ingen måte trivielt. Den komplekse frigjøringsprosessen fra jugoslavisk historie når et klimaks i Bosnia-Hercegovina. Ifølge Goran 
Simić fremstår post-Dayton-historieundervisning her som en fortsettelse av krigen med andre midler: Partene ble påtvunget en fredsavtale utenfra uten at problemet hadde blitt løst på bakken, og dermed fortsatte oppgjøret via historiepensum. Det finnes ingen felles historie, men tre forskjellige, parallelle historiepensumer avhengig av om elevene bor i et bosnjakisk-, serbisk- eller kroatiskdominert område.

Til tross for mange gode enkeltstudier, savner jeg til tider et sterkere grep fra redaktørenes side. Det finnes en underliggende geografisk logikk, men denne forsvinner i de svært ulike vinklingene som kapittelforfatterne anlegger. For eget vedkommende ville jeg nok hatt større utbytte av lesingen om kapitlene hadde blitt klarere organisert i henhold til tematikk. Redaktørene utnytter også i liten grad det rike potensialet for komparative innsikter som ligger i materialet - både gjennom systematisk sammenligning mellom før og etter oppløsningen av Jugoslavia og på tvers av de nye, selvstendige statene. Selv om redaktørene trekker opp noen linjer i innledningskapitlet, ville boken også stått seg på et mer tradisjonelt konklusjonskapittel hvor trådene ble samlet. Nå avspises vi med kun 17 linjer - på ingen måte nok til å yte materialet rettferdighet. Disse kritiske betraktningene til tross: Nationhood and Politization of History in School Textbooks gir oss et mangefasettert bilde av utfordringene knyttet til utforming og formidling av nasjonal historie i et politisk ustabilt landskap. 